\title{
TINGKAT KESEJAHTERAAN KELUARGA PETANI PADI SAWAH DAN JAGUNG DI DESA MATANI, KECAMATAN TUMPAAN, KABUPATEN MINAHASA SELATAN
}

\author{
Liby Rosany Lampah \\ Oktavianus Porajouw \\ Gene H. M. Kapantow
}

\begin{abstract}
This study aims to compare the level of welfare of farmers who seek in the field of wetland rice and corn farmers in the Village Matani Tumpaan District in South Minahasa. The study lasted from July to September 2017. The data used are primary data collected throught interviews with farmers by purposive sampling taken 15 corn farmers and 15 rice field farmers. The study on farmers' welfare level is seen from the form of economic and non economic variables enjoyed by respondents based on the criteria of BKKBN covering 5 stages of family welfare indicators. Secondary data is obtained throught documents and research results and library, data and information in village, sub-district and district offices. The result of this research concludes that rice farmers are more prosperous than corn farmers in Matani Village Tumpaan Subdistrict of South Minahasa Regency. Wet land paddy farmers are included in the stages of the Prosperous Family II (KS II) and Prosperous Family III (KS III) while corn farmers are included in the stage of the Prosperous Family I (KS I).
\end{abstract}

Keywords: level of welfare, rice and maize farmers, prosperous family, Matani Village, Tumpaan Sub-district, South Minahasa Regency

\begin{abstract}
ABSTRAK
Penelitian bertujuan untuk membandingkan tingkat kesejahteraan petani yang berusaha di bidang padi sawah dan petani jagung di Desa Matani Kecamatan Tumpaan di Minahasa Selatan. Penelitian berlangsung mulai dari bulan Juli 2017 sampai September 2017. Data primer dikumpulkan melalui wawancara dengan petani secara purposive sampling diambil 15 petani jagung dan 15 petani padi sawah. Kajian tingkat kesejahteraan petani dilihat dari bentuk variabel ekonomi dan nonekonomi yang dinikmati oleh responden berdasarkan kriteria dari BKKBN yang meliputi 5 tahapan indikator kesejahteraan keluarga. Data sekunder diperoleh melalui dokumen dan hasil penelitian kepustakaan serta data dan informasi yang berada di kantor desa, kecamatan maupun kabupaten. Hasil penelitian menunjukkan bahwa petani padi sawah lebih sejahtera dari pada petani jagung di Desa Matani Kecamatan Tumpaan Kabupaten Minahasa Selatan. Petani padi sawah termasuk dalam tahapan Keluarga Sejahtera II (KS II) dan Keluarga Sejahtera III (KS III) sedangkan petani jagung termasuk dalam tahapan Keluarga Sejahtera I (KS I)
\end{abstract}

Kata kunci: tingkat kesejahteraan keluarga, petani padi sawah dan jagung, keluarga sejahtera, Desa Matani, Kecamatan Tumpaan, Kabupaten Minahasa Selatan 


\section{PENDAHULUAN}

\section{Latar Belakang}

Keterbatasan lahan dan kemiskinan di daerah pedesaan, serta tidak tersedianya lapangan pekerjaan yang sesuai dengan pengetahuan dan keterampilan di daerah perkotaan menjadi penyebab ada yang bekerja tetap sebagai petani namun dalam komoditi yang berbeda-beda sesuai dengan lahan yang tersedia di desa. Masih banyak petani yang tetap bertahan dalam bidang usahataninya karena tidak ada keterampilan lain di luar usahatani. Akibat dari keadaan ini menyebabkan petani berusaha di bidang pertanian walaupun jenis usaha berbeda dengan petani yang lain yang penting mereka tetap bertahan hidup dengan usahataninya.

Perbedaan usahatani ini menjadikan perbedaan pendapatan antara petani yang berusahatani menurut komoditi masingmasing berpengaruh langsung terhadap kesejahteraan masyarakat di desa dan mempengaruhi produktivitas di kalangan petani. Gambaran bahwa tingkat kesejahteraan masyarakat di pedesaan juga berbeda sesuai dengan usahatani yang digelutinya.

Kondisi petani di Sulut dinilai belum sejahtera, hal ini dibuktikan dengan Nilai Tukar Petani (NTP) Sulut yang masih dibawah 100 yang menunjukkan masih tingginya biaya produksi daripada pendapatan petani. Selain NTP yang masih dibawah 100, kondisi petani juga masih belum berada di taraf sejahtera. Berdasarkan data Badan Pusat Statistika (BPS) untuk bulan Agustus 2017 NTP petani berada di angka 92,26 atau turun $0,07 \%$ dari NTP bulan Juli yaitu 92,32. Angka ini dipengaruhi masih besarnya pengeluaran yang harus dibayarkan petani ketimbang harga yang diterimanya saat menjual hasil pertanian. Penurunan angka NTP membuat NTP Sulut tak kunjung membaik. Posisi tertinggi terjadi pada bulan Agustus 2016 yakni 96,93. Idealnya NTP 100 untuk mengukur taraf kesejahteraan petani. tetapi setelah itu turun hingga berada pada titik terendah bulan Maret 2017 yaitu sebesar 91,65. (BPS, 2017). Keadaan ini kalau tidak dilakukan kebijakan dan kajiankajian yang tepat, bukan hanya aktivitasaktivitas ekonomi tradisional yang akan punah, tetapi juga tingkat kesejahteraan masyarakat akan jauh dari harapan. Untuk itu perlu informasi dan gambaran umum tentang kajian tingkat kesejahteraan masyarakat petani dengan kasus masyarakat di desa Matani Kecamatan Tumpaan Kabupaten Minahasa Selatan.

Dipilihnya desa tersebut dengan alasan bahwa Desa Matani merupakan bagian dari Kecamatan Tumpaan dengan mayoritas penduduk yang berusaha di bidang pertanian padi sawah dan masih ada masyarakat yang berusaha tani di luar padi sawah seperti jagung, kelapa dan sebagainya.

\section{Perumusan Masalah}

Berdasarkan latar belakang yang telah dikemukakan, maka yang menjadi masalah dalam penelitian ini yaitu: Bagaimana tingkat kesejahteraan petani yang berusaha di bidang padi sawah dengan petani jagung di Desa Matani Kecamatan Tumpaan?

\section{Tujuan Penelitian}

Penelitian ini bertujuan untuk membandingkan tingkat kesejahteraan petani yang berusaha di bidang padi sawah dan petani jagung di Desa Matani Kecamatan Tumpaan

\section{Manfaat Penelitian}

Dengan adanya penelitian ini diharapkan dapat memberikan

1. Bahan masukan bagi pihak pemerintah dalam usaha meningkatkan kesejahteraan masyarakat dalam merumuskan kebijakan pembangunan yang dapat meningkatkan kesejahteraan ekonomi masyarakat, dan pengembangan masyarakat.

2. Sebagai bahan referensi bagi peneliti lain, yang berminat dalam bidang kesejahteraan masyarakat dan pengembangan ekonomi daerah. 


\section{METODOLOGI PENELITIAN}

Waktu dan Tempat Penelitian

Penelitian berlangsung selama tiga bulan, yaitu bulan Juli, Agustus dan September 2017. Tempat penelitian di Desa Matani Kecamatan Tumpaan Kabupaten Minahasa Selatan.

\section{Metode Pengumpulan Data}

Data primer diperoleh melalui wawancara dilakukan dengan menggunakan daftar pertanyaan dengan indikator-indikator kesejahteraan keluarga berdasarkan tahapan menurut BKKBN. Data sekunder melalui dokumen dan hasil penelitian kepustakaan serta data dan informasi yang berada di kantor kecamatan, kabupaten/kota yang terkait dengan permasalahan.

\section{Metode Penarikan Sampel}

Keadaan kesejahteraan keluarga petani padi sawah dan petani jagung, dilakukan dengan menggunakan sampel dengan pengambilan secara sengaja (purposive sampling) dengan masing-masing usahatani diambil 15 kepala keluarga (responden) dengan pengelompokkan dalam 2 kegiatan usahatani yaitu padi sawah dan jagung. Variabel kesejahteraan terlihat dari bentuk variabel ekonomi dan nonekonomi yang dinikmati oleh responden berdasarkan kriteria dari BKKBN yang meliputi 5 tahapan indikator kesejahteraan keluarga.

\section{Konsep dan Indikator}

Tingkat kesejahteraan merupakan kemampuan petani di Desa Matani, Kecamatan Tumpaan, Kabupaten Minahasa Selatan, untuk memenuhi kebutuhan pokok, baik itu kebutuhan akan makanan, pakaian, tempat tinggal, serta kesempatan untuk melanjutkan pendidikan dan memiliki pekerjaan yang memadai yang dapat menunjang kualitas hidup sehingga memiliki status sosial yang sama terhadap sesama warga lainnya menurut indikator tahapan keluarga sejahtera yang dikemukakan BKKBN yaitu:
1. Enam Indikator tahapan Keluarga Sejahtera I (KS I) atau indikator "kebutuhan dasar keluarga" (basic needs), dari 21 indikator keluarga sejahtera yaitu:

a. Pada umumnya anggota keluarga makan dua kali sehari atau lebih.

b. Anggota keluarga memiliki pakaian yang berbeda untuk di rumah, bekerja/sekolah dan bepergian.

c. Rumah yang ditempati keluarga mempunyai atap, lantai dan dinding yang baik.

d. Bila ada anggota keluarga sakit dibawa ke sarana kesehatan.

e. Bila pasangan usia subur ingin ber KB pergi ke sarana pelayanan kontrasepsi.

f. Semua anak umur 7-15 tahun dalam keluarga bersekolah.

2. Delapan indikator Keluarga Sejahtera II (KS II) atau indikator "kebutuhan psikologis" (psychological needs) keluarga, dari 21 indikator keluarga sejahtera yaitu:
a. Pada umumnya anggota keluarga melaksanakan ibadah sesuai dengan agama dan kepercayaan masing-masing.
b. Paling kurang sekali seminggu seluruh anggota keluarga makan daging/ ikan/telur.
c. Seluruh anggota keluarga memperoleh paling kurang satu stel pakaian baru dalam setahun.
d. Luas lantai rumah paling kurang $8 \mathrm{~m} 2$ untuk setiap penghuni rumah.
e. Tiga bulan terakhir keluarga dalam keadaan sehat sehingga dapat melaksanakan tugas/fungsi masing- masing.

f. Ada seorang atau lebih anggota keluarga yang bekerja untuk memperoleh penghasilan.

g. Seluruh anggota keluarga umur 10 60 tahun bisa baca tulisan latin.
h. Pasangan usia subur dengan anak dua atau lebih menggunakan alat/obat kontrasepsi.

3. Lima indikator Keluarga Sejahtera III (KS III) atau indikator "kebutuhan pengembangan" (develomental needs), dari 21 indikator keluarga sejahtera yaitu: 
a. Keluarga berupaya meningkatkan pengetahuan agama.

b. Sebagian penghasilan keluarga ditabung dalam bentuk uang atau barang.

c. Kebiasaan keluarga makan bersama paling kurang seminggu sekali dimanfaatkan untuk berkomunikasi.

d. Keluarga ikut dalam kegiatan masyarakat di lingkungan tempat tinggal.

e. Keluarga memperoleh informasi dari surat kabar/majalah/ radio/tv/internet.

4. Dua indikator Kelarga Sejahtera III Plus (KS III Plus) atau indikator "aktualisasi diri" (self esteem) dari 21 indikator keluarga, yaitu:

a. Keluarga secara teratur dengan suka rela memberikan sumbangan materiil untuk kegiatan sosial.

b. Ada anggota keluarga yang aktif sebagai pengurus perkumpulan sosial/yayasan/ institusi masyarakat.

\section{Metode Analisis}

Tingkat kesejahteraan keluarga diukur dengan 5 tahapan indikator yang dikembangkan oleh BKKBN tahun 2015 yaitu indikator keluarga sejahtera yang terdiri dari 5 tahapan dan 21 indikator. Berdasarkan indikator tersebut kemudian diberi kategori tingkat kesejahteraan dari 5 tahap. Metode analisis yang digunakan yaitu analisis deskriptif yang disajikan dengan menggunakan tabel kemudian diinterpretasi untuk penarikan kesimpulan.

\section{HASIL DAN PEMBAHASAN}

\section{Gambaran Umum Daerah Penelitian}

\section{Sejarah Desa}

Desa Matani adalah sebuah desa yang berada di Kecamatan Tumpaan Kabupaten Minahasa Selatan. Desa ini berdiri sejak tahun 1942 yang merupakan pecahan dari Desa Tumpaan pada waktu itu. Penduduk awal Desa Matani adalah orang-orang Tountemboan (orang-orang dari gunung) yang mengolah kebun lading serta kebun sawah dan nelayan (orang Bugis) yang melaut kemudian membuat daseng (pondok-pondok) di pinggir pantai yang kemudian dengan sendirinya membentuk kehidupan. Desa Matani waktu itu terdiri dari 2 jaga dan langsung berdiri sendiri lepas dari Desa Tumpaan.

Seiring dengan perkembangan, penduduk Desa Matani semakin maju dan berkembang bersamaan dengan bertambahnya penduduk dari tahun ke tahun. Sejak tahun 2004 sudah terdapat 10 jaga dan pada tanggal 08 Agustus 2007 dengan berbagai pertimbangan maka desa Matani dimekarkan menjadi dua desa yaitu Desa Matani dan Desa Matani Satu, yang masing-masing dipimpin oleh pemerintah desa yakni Kepala Desa. Desa Matani terdiri dari 6 (enam) wilayah (dusun/jaga) dan tiap jaga dibawah pemerintahan seorang kepala jaga dan dibantu oleh seorang pembantu kepala jaga yang disebut Meweteng.

\section{Keadaan Wilayah}

Desa Matani terletak di sebelah utara

Kabupaten Minahasa Selatan Provinsi Sulawesi Utara dan termasuk salah satu desa di wilayah Kecamatan Tumpaan. Luas wilayah yaitu 202 ha, terdiri dari tanah perkebunan 140 ha, tanah sawah 50 ha, tegalan/kebun 2 ha dan hutan 10 ha dengan karakteristik daerah pantai, dataran dan perbukitan. Sumberdaya alam bidang pertanian yaitu kelapa, cengkih, jagung dan padi sawah. Bidang peternakan yaitu ayam, itik, sapi dan babi. Adapun batas wilayah Desa Matani sebagai berikut: sebelah utara berbatasan dengan Desa Popontolen, sebelah timur berbatasan dengan Desa Kapoya, sebelah selatan berbatasan dengan Desa Tumpaan dan sebelah barat berbatasan dengan Laut Sulawesi. Jarak ke pusat pemerintahan kecamatan $+1,5 \mathrm{~km}$, ke pusat pemerintahan kabupaten $\pm 4 \mathrm{~km}$ dan jarak ke pusat pemerintahan provinsi $\pm 44 \mathrm{~km}$. 


\section{Keadaan Penduduk dan Pendidikan}

Jumlah penduduk Desa Matani yaitu 1.679 jiwa terdiri dari laki-laki 663 jiwa $(39,49 \%)$ dan perempuan 1.016 jiwa $(60,51 \%)$ dengan jumlah kepala keluarga 352 KK. Jumlah keluarga Pra Sejahtera 167 KK dan Keluarga Sejahtera 185 KK. Terdapat satu buah Sekolah Dasar sebagai sarana pendidikan yang ada di desa ini dengan tingkat pendidikan penduduk sebagai berikut:

Tabel 1. Penduduk menurut Tingkat Pendidikan di Desa Matani

\begin{tabular}{llc}
\hline No & \multicolumn{1}{c}{ Pendidikan } & Jumlah (jiwa) \\
\hline 1. & Tidak tamat SD & 537 \\
2. & Tamat SD & 847 \\
3. & Tamat SLTP & 200 \\
4. & Tamat SLTA & 80 \\
5. & Sarjana (S1) & 15 \\
\hline
\end{tabular}

Sumber: Kantor Desa Matani, 2014.

\section{Kesehatan dan Ekonomi Masyarakat}

Desa Matani memiliki Posyandu, Klinik Bersalin dan Puskesmas. Bidan melayani setiap hari dan kader kesehatan yang bertugas sebulan sekali. Tim kesehatan dari kecamatan mengadakan kunjungan setiap bulan di desa ini. Angka kematian bayi dan ibu relatif kecil bahkan tidak ada dalam kurun waktu dua tahun terakhir. Hal ini disebabkan kader kesehatan yang berfungsi dengan baik dalam menjalankan tugasnya serta adanya peningkatan pengetahuan tentang kesehatan ibu dan anak (KIA).

Pertumbuhan perekonomian desa sangat pesat ditandai dengan tumbuhnya usaha-usaha di bidang perdagangan seperti warung sembako, barang kelontong, warung makan, industri rumah tangga dan pertukangan serta usaha jasa transportasi. Meskipun pendapatan asli daerah (PAD) masih rendah, namun ada alokasi dana desa dan bantuan dari pihak ketiga yang umumnya tidak mengikat. Jarak tempuh yang sangat dekat dengan pasar kecamatan sehingga mempermudah masyarakat untuk memenuhi kebutuhan hidup sehari-hari. Kemajuan teknologi berkembang pesat dengan adanya jaringan telepon genggam, dan akses internet makin mempermudah masyarakat dalam memperoleh berbagai informasi.

\section{Deskripsi Responden}

Karakteristik petani responden terdiri dari 15 petani jagung dan 15 petani padi sawah di Desa Matani Kecamatan Tumpaan yang meliputi umur, tingkat pendidikan, pengalaman berusahatani (lamanya menjadi petani) dan rata-rata penghasilan per bulan ditunjukkan dalam pada Tabel 2 berikut:

Tabel 2. Karakteristik Responden Petani Jagung dan Padi Sawah di Desa Matani Kecamatan Tumpaan

\begin{tabular}{|c|c|c|c|}
\hline No & $\begin{array}{l}\text { Karakteristik } \\
\text { Responden }\end{array}$ & $\begin{array}{c}\text { Petani } \\
\text { Jagung } \\
(n=15)\end{array}$ & $\begin{array}{c}\text { Petani Padi } \\
\text { Sawah } \\
(n=15)\end{array}$ \\
\hline$\overline{1}$ & Rata-rata umur (tahun) & 56 & 51,2 \\
\hline 2 & $\begin{array}{r}\text { Tkt Pendidikan: SD } \\
\text { SMP } \\
\text { SMA }\end{array}$ & $\begin{array}{r}13 \\
2 \\
-\end{array}$ & $\begin{array}{c}14 \\
- \\
1\end{array}$ \\
\hline 3 & $\begin{array}{l}\text { Pengalaman usaha tani } \\
\text { (tahun) }\end{array}$ & 32,2 & 31,2 \\
\hline 4 & $\begin{array}{c}\text { Status Rumah Tinggal: } \\
\text { - Milik } \\
\text { sendiri } \\
\text { - Menumpang }\end{array}$ & $\begin{array}{r}14 \\
1\end{array}$ & $\begin{array}{r}14 \\
1\end{array}$ \\
\hline 5 & $\begin{array}{c}\text { Pekerjaan sampingan: } \\
\text { - Menjahit } \\
\text { - Beternak } \\
\text { - Panjat } \\
\text { kelapa } \\
\text { - Tani sayur } \\
\text { - Nelayan } \\
\end{array}$ & $\begin{array}{l}1 \\
1 \\
- \\
- \\
-\end{array}$ & $\begin{array}{l}- \\
- \\
1 \\
1 \\
1\end{array}$ \\
\hline
\end{tabular}

Sumber: Data Primer, 2017

Berdasarkan mata pencaharian utama sebagai petani dibedakan petani jagung dan petani padi sawah yang dominan di Desa Matani. Petani padi sawah rata-rata umur 51,2 tahun dengan interval umur antara 39 sampai 68 tahun. Keadaan ini juga berhubungan langsung dengan pengalaman (lamanya berusahatani) tidak berbeda jauh dengan jenis usahatani yakni petani jagung rata-rata berpengalaman 32,2 tahun sedangkan petani padi sawah 31,2 tahun. Tampak bahwa usia petani baik di jagung maupun pada padi sawah berusia diatas 40 tahun. Untuk yang 
berusia muda rupanya jarang berprofesi petani lebih banyak berusaha di bidang non pertanian seperti tukang ojek, usaha warung, barang kelontong, warung makan dan pertukangan.

Tingkat pendidikan responden berdasarkan hasil penelitian di lapangan untuk petani jagung 13 responden Sekolah Dasar dan ada 2 responden SMP. Tidak jauh berbeda dengan petani padi sawah yakni tingkat Sekolah Dasar sebanyak 14 responden dan hanya 1 tingkat SMA. Hal ini ditunjukkan juga dengan tingkat pendidikan seluruh penduduk di Desa Matani paling banyak di dominasi tingkat pendidikan Sekolah Dasar (Tabel 1). Dengan demikian tingkat pendidikan tidak ada hubungannya dengan petani yang berusahatani jagung maupun usahatani padi sawah, semua didominasi tingkat pendidikan Sekolah Dasar.

Status rumah tinggal, baik petani jagung maupun petani padi sawah mempunyai status rumah tinggal milik sendiri masing-masing ada 14 responden milik sendiri dan masing-masing ada 1 petani yang menumpang dengan keluarga yang lain. Sama halnya dengan pekerjaan sampingan, pada usahatani jagung ada 1 responden yang mempunyai usaha sampingan yaitu menjahit dan ada yang beternak. Pada usahatani padi sawah, ada petani yang mempunyai usaha sampingan sebagai panjat kelapa dan petani yang lain sebagai nelayan dan bertanam sayur-sayuran.

Tabel 3 berikut menunjukkan pendapatan rata-rata petani jagung dan petani padi sawah per hasil panen di Desa Matani Kecamatan Tumpaan Minahasa Selatan.

Tabel 3. Pendapatan Rata-rata Rp/Panen Petani Jagung dan Padi Sawah di Desa Matani Kecamatan Tumpaan

\begin{tabular}{llcc}
\hline No & Pendapatan & $\begin{array}{c}\text { Pendapatan } \\
\text { Petani Jagung } \\
(\mathbf{R p})\end{array}$ & $\begin{array}{c}\text { Pendapatan } \\
\text { Petani Padi } \\
\text { Sawah }(\text { Rp) }\end{array}$ \\
\hline 1 & Setiap Panen & 2.193 .000 & 5.106 .000 \\
2 & Per Tahun & 8.772 .000 & 20.424 .000 \\
\hline
\end{tabular}

Sumber: Data Primer, 2017
Tabel 3 menunjukkan bahwa pendapatan rata-rata dalam rupiah per panen untuk keluarga petani jagung lebih rendah dibandingkan dengan rata-rata pendapatan per panen petani padi sawah. Untuk usahatani jagung rata-rata $\mathrm{Rp}$ 2.193.000/panen sedangkan petani padi sawah lebih tinggi 2,3 kali dari petani jagung yaitu Rp 5.106.000/panen. Pada hal jika menurut umur dan pengalaman berusahatani, tingkat pendidikan, kepemilikan/status rumah tinggal, tidak berbeda antara petani jagung dan padi sawah. Pendapatan petani sangat tergantung dengan banyaknya hasil panen yang diperoleh. Petani jagung diperhadapkan dengan fluktuasi harga yang ada di pasaran, sedangkan untuk petani padi sawah jika sebagai penyewa maupun penggarap harus membagi hasil dengan pemilik.

\section{Tingkat Kesejahteraan Masyarakat}

Jumlah kepala keluarga penduduk di Desa Matani sebanyak $352 \mathrm{KK}$, dari jumlah ini sebanyak $167 \mathrm{KK}(47,44 \%)$ tergolong dalam kategori Keluarga Pra Sejahtera dan 185 KK $(52,56 \%)$ kategori Keluarga Sejahtera. Hasil penelitian temuan di lapangan pengukuran tingkat kesejahteraan berdasarkan tahapan kesejahteraan keluarga yang dikembangkan oleh BKKBN yang terdiri dari 21 indikator dan dibagi menjadi 5 tahapan yaitu Keluarga Pra Sejahtera, Keluarga Sejahtera Tahap I (KS I), Keluarga Sejahtera Tahap II (KS II), Keluarga Sejahtera Tahap III (KS III) dan Keluarga Sejahtera Tahap III Plus (KS III +).

Tabel 4. Distribusi Tingkat Kesejahteraan Berdasarkan Tahapan Kesejahteraan Keluarga di Desa Matani

\begin{tabular}{|c|c|c|c|c|c|}
\hline No & $\begin{array}{l}\text { Tingkat } \\
\text { Kesejahteraan }\end{array}$ & Jagung & $\begin{array}{l}\text { Jumlah } \\
\%\end{array}$ & $\begin{array}{l}\text { Petani } \\
\text { Padi } \\
\text { Sawah }\end{array}$ & $\%$ \\
\hline 1 & $\begin{array}{l}\text { Keluarga Pra } \\
\text { Sejahtera }\end{array}$ & - & - & - & - \\
\hline 2 & $\begin{array}{l}\text { Keluarga } \\
\text { Sejahtera I (KS I) }\end{array}$ & 14 & 93.33 & - & - \\
\hline 3 & $\begin{array}{l}\text { Keluarga } \\
\text { Sejahtera II (KS } \\
\text { II) }\end{array}$ & - & - & 10 & 66,67 \\
\hline 4 & $\begin{array}{l}\text { Keluarga } \\
\text { Sejahtera III (KS } \\
\text { III) }\end{array}$ & - & - & 5 & 33,33 \\
\hline 5 & $\begin{array}{l}\text { Keluarga } \\
\text { Sejahtera III Plus } \\
\text { (KS III +) }\end{array}$ & 1 & 6,67 & - & - \\
\hline & Jumlah & 15 & 100 & 15 & 100 \\
\hline
\end{tabular}

Sumber: Data Primer, 2017 
Tabel 4 menunjukkan bahwa tidak terdapat keluarga petani baik petani jagung maupun petani padi sawah yang termasuk dalam Keluarga Pra Sejahtera (keluarga sangat miskin). Pada petani jagung terdapat 14 responden $(93,33 \%)$ tergolong dalam kategori Keluarga Sejahtera I (KS I) dimana indikator yang tidak terpenuhi dalam kategori ini yaitu semuanya mempunyai luas lantai rumah lebih kecil dari $8 \mathrm{~m} 2$ untuk setiap penghuni rumah (luas keseluruhan lantai dapur, kamar mandi, kamar tidur dan ruang tamu). Ada sekitar 5 petani jagung yang di dalam keluarga tidak ada anggota keluarga yang lain bekerja untuk memperoleh penghasilan dan 2 petani dengan anggota keluarga yang berumur 10-60 tahun yang tidak bisa baca tulis. Keadaan inilah yang membuat petani jagung tergolong dalam kategori Keluarga Sejahtera I (KS I)/keluarga miskin karena tidak memenuhi beberapa kriteria tersebut, baik secara ekonomi (luas lantai rumah) maupun secara non ekonomi (1060 tahun bisa baca tulis).

Ada $1(6,67 \%)$ petani jagung yang tergolong dalam Keluarga Sejahtera III Plus $(\mathrm{KS}$ III +) dimana petani tersebut mempunyai usaha sampingan sebagai peternak. Keluarga Sejahtera III Plus (KS III Plus) adalah keluarga yang telah dapat memenuhi kebutuhan dasar minimum, kebutuhan dasar psikologis, kebutuhan pengembangan, dan sekaligus secara teratur ikut menyumbang dalam kegiatan sosial dan aktif mengikuti gerakan semacam itu. Adapun syarat agar dapat dikatakan sebagai Keluarga Sejahtera III Plus adalah mampu memenuhi indikator 1-21 ditambah indikator sebagai berikut: keluarga atau anggota keluarga secara teratur memberikan sumbangan bagi kegiatan sosial masyarakat dalam bentuk materi dan kepala keluarga atau anggota keluarga aktif sebagai pengurus perkumpulan, yayasan, atau institusi masyarakat lainnya.

Petani padi sawah secara umum lebih sejahtera dibandingkan dengan petani jagung (Tabel 4). Terdapat 10 Keluarga $(66,67 \%)$ yang tergolong dalam kategori Keluarga Sejahtera II (KS II) dengan indikator yang tidak terpenuhi seperti tidak menabung baik dalam bentuk uang maupun barang serta ada satu keluarga yang tidak pernah makan bersama dalam satu meja untuk berkomunikasi. Sebanyak 5 orang $(33,33 \%)$ petani padi sawah tergolong dalam kategori Keluarga Sejahtera III (KS III) dengan indikator yang tidak terpenuhi yaitu tidak ada anggota keluarga yang menjadi pengurus atau panitia dalam organisasi sosial maupun lembaga atau pemerintah. Ada satu keluarga yang tidak memenuhi indikator tidak memberikan sumbangan apapun baik berupa uang maupun barang.

Bagi petani yang dapat memenuhi semua indikator keluarga sejahtera dari BKKBN dari kategori 1 sampai 21 atau termasuk dalam Keluarga Sejahtera Tahap III+ hanya ada satu petani jagung dan hal ini disebabkan karena petani tersebut mempunyai usaha sampingan sebagai peternak. Namun, bagi petani-petani yang tidak dapat memenuhi salah satu indikator dari BKKBN ini bukan berarti tidak dapat memenuhi indikator selanjutnya, dikarenakan sistem pentahapan yang ketat dan berbentuk hierarkis yang merupakan ciri dari model pengukuran kesejahteraan keluarga ini untuk mendapatkan tingkat kesejahteraan yang sesungguhnya (kesejahteraan keluarga secara ekonomi dan sosial). Tingkat kesejahteraan keluarga petani secara ekonomi belum tentu dapat mengindikasikan tingkat kesejahteraan yang sesungguhnya. Kesejahteraan pada hakekatnya terdiri dari dua dimensi yaitu kesejahteraan secara ekonomi dan secara sosial. Dengan mengacu pada definisi kesejahteraan tersebut dan manusia sebagai mahluk sosial maka pemerintah dalam hal ini BKKBN memberikan tahapan-tahapan kesejahteraan untuk mengukur tingkat kesejahteraan secara sosial dan ekonomi yang sangat deskriptif dan mudah dipahami.

Berdasarkan hasil penelitian yang dirangkum pada Tabel 4 terlihat bahwa petani yang tergolong dalam kategori Keluarga Sejahtera II dan Keluarga Sejahtera III terdapat 
pada petani padi sawah. Seperti diketahui bahwa pertanian yang dominan di Desa Matani yaitu padi sawah dan tanaman tahunan kelapa. Hal ini dikerjakan petani sudah sejak dahulu secara turun temurun dan di dukung oleh lahan yang luas. Petani jagung hanya memanfaatkan lahan yang ada yang relatif kecil. Dengan demikian petani padi sawah relatif lebih sejahtera dibandingkan dengan petani jagung. Diperlukan usaha yang lain sebagai usaha sampingan untuk menambah pendapatan bagi petani jagung tidak hanya mengandalkan tanaman jagung saja. Petani padi sawah yang termasuk dalam kategori Keluarga Sejahtera III mempunyai usaha sampingan yang lain seperti memanjat kelapa, bertanam sayuran untuk di jual di pasar dan ada yang sebagai nelayan. Hal ini dilakukan karena menunggu panenan padi yang dilakukan 3 bulanan. Lain halnya dengan petani jagung sebagian besar tidak mempunyai usaha sampingan.

Menurut Sawit (1979) usaha tani banyak mengandung resiko dan ketidakpastian, seperti misalnya kalau gagal panen, produksi merosot atau rendah karena serangan hama dan penyakit, kekeringan karena kemarau yang panjang atau banjir pada saat musim hujan atau kebakaran. Untuk itu menurutnya diperlukan pekerjaan dan pendapatan tambahan guna mengatasi masalah peningkatan pendapatan bagi masyarakat di pedesaan. Pada masyarakat pedesaan yang masih menggantungkan hidup dari sektor pertanian, luas penguasaan lahan terutama lahan pertanian sangatlah penting karena lahan pertanian bagi mereka merupakan modal. Namun tidak demikian dengan masyarakat yang tidak mempunyai lahan mereka terpaksa harus mencari jalan lain untuk kelangsungan hidup mereka.

Petani jagung yang ada di Desa Matani, hanya 2 responden yang mempunyai usaha sampingan yaitu sebagai peternak dan penjahit pakaian sisanya yang 13 responden hanya mengandalkan pertanian tanaman jagung. Walaupun mempunyai rumah tinggal yang berstatus milik sendiri akan tetapi tidak memenuhi syarat untuk masuk dalam Keluarga Sejahtera II karena kategori luas lantai rumah paling kurang $8 \mathrm{~m} 2$ untuk setiap penghuni rumah (luas keseluruhan lantai dapur, kamar mandi, kamar tidur dan ruang tamu) lebih kecil dari $8 \mathrm{~m} 2$. Dengan demikian petani jagung ini hanya termasuk dalam Keluarga Sejahtera I (KS I) yang menurut $\mathrm{BKKBN}$ masih tergolong miskin hanya memenuhi kebutuhan dasar keluarga (basic needs). Pada rumah tangga yang tergolong miskin dalam usaha memenuhi kebutuhan, terutama pangan, sebagian besar penghasilan digunakan untuk membeli kebutuhan seperti beras, lauk pauk dan sayuran. Pengeluaran untuk non pangan pada rumah tangga dianggap kurang penting. Bagi mereka yang penting dapat makan walaupun hanya dengan sayuran. Kebutuhan pangan bagi masyarakat di pedesaan merupakan kebutuhan yang sangat vital agar dapat bertahan hidup.

Petani padi sawah yang ada di Desa Matani berdasarkan hasil penelitian dari 15 petani padi sawah sebanyak 10 petani tergolong dalam Keluarga Sejahtera II (KS II) yakni keluarga yang dapat memenuhi "kebutuhan psikologis" (psychological needs) keluarga, yakni keluarga melaksanakan ibadah yang dilakukan sendiri maupun bersama-sama keluarga baik di rumah maupun di tempat lain di luar rumah, paling kurang sekali seminggu seluruh anggota keluarga makan daging/ikan/telur, seluruh anggota keluarga memperoleh paling kurang satu stel pakaian baru dalam setahun, luas lantai rumah paling kurang $8 \mathrm{~m} 2$ untuk setiap penghuni rumah, tiga bulan terakhir keluarga dalam keadaan sehat sehingga dapat melaksanakan tugas/fungsi masing-masing ada seorang atau lebih anggota keluarga yang bekerja untuk memperoleh penghasilan, seluruh anggota keluarga umur 10 sampai 60 tahun bisa baca tulisan latin. Indikator yang tidak terpenuhi dalam tahapan keluarga sejahtera ini yaitu tidak menabung.

Sebanyak 5 responden petani padi sawah di Desa Matani termasuk dalam Keluarga Sejahtera III (KS III) yakni tergolong dalam indikator "kebutuhan pengembangan" (develomental needs), dimana dalam kategori ini keluarga berupaya meningkatkan pengetahuan agama adalah upaya untuk meningkatkan pengetahunan agama berupa anak-anak diikutkan dalam ibadah sekolah minggu, mengikuti kegiatan KKR yang 
diadakan oleh gereja, sebagian penghasilan keluarga ditabung dalam bentuk uang atau barang, kebiasaan keluarga makan bersama adalah kebiasaan seluruh anggota keluarga untuk makan bersama sama, sehingga waktu sebelum atau sesudah makan dapat digunakan untuk komunikasi membahas persoalan yang dihadapi dalam satu minggu atau untuk berkomunikasi dan bermusyawarah antar seluruh anggota keluarga. Keluarga ikut dalam kegiatan masyarakat di lingkungan tempat tinggal berupa keikutsertaan seluruh atau sebagian dari anggota keluarga dalam kegiatan masyarakat di sekitarnya yang bersifat sosial kemasyarakatan, seperti gotong royong, ronda malam, rapat $\mathrm{RT}$, arisan, pengajian, kegiatan PKK, kegiatan kesenian, olah raga dan sebagainya. Keluarga memperoleh informasi dari surat kabar/ majalah/ radio/tv/internet adalah tersedianya kesempatan bagi anggota keluarga untuk memperoleh akses informasi baik secara lokal, nasional, regional, maupun internasional, melalui media cetak (seperti surat kabar, majalah, bulletin) atau media elektronik (seperti radio, televisi, internet). Indikator yang tidak memenuhi kriteria sehingga 5 responden ini tidak termasuk dalam kategoiri tahapan Keluarga Sejahtera III Plus (KS III +) hanya karena mereka tidak ada anggota keluarga yang aktif sebagai pengurus perkumpulan sosial atau institusi masyarakat. Keluarga yang tidak menjadi pengurus pada berbagai organisasi/kepanitiaan (seperti pengurus pada organisasi adat, kesenian, olah raga, keagamaan, kepemudaan, institusi masyarakat, pengurus RT/RW, LKMD/LMD dan sebagainya).

\section{KESIMPULAN DAN SARAN}

\section{Kesimpulan}

Hasil penelitian menunjukkan bahwa petani padi sawah lebih sejahtera dari pada petani jagung di Desa Matani Kecamatan Tumpaan Kabupaten Minahasa Selatan. Petani padi sawah termasuk dalam tahapan Keluarga Sejahtera II (KS II) dan Keluarga Sejahtera III (KS III) sedangkan petani jagung termasuk dalam tahapan Keluarga Sejahtera I (KS I).

\section{Saran}

1. Bagi petani jagung, harus ada usaha sampingan lain untuk meningkatkan pendapatan sehingga tahapan keluarga sejahtera meningkat.

2. Peningkatan kesejahteraan keluarga di Desa Matani Kecamatan Tumpaan tidak hanya peningkatan pendapatan dalam bentuk bantuan dana yang selama ini diberikan akan tetapi lebih diarahkan pada pengembangan usaha ekonomi keluarga diikuti dengan pentingnya kesadaran atau memberikan motivasi tentang pentingnya pendidikan.

\section{DAFTAR PUSTAKA}

Anonimous. 1996. Kajian Ekonomi Rakyat: Agenda Penelitian. Biro Tenaga Kerja dan Pengembangan Kesempatan Kerja. Tahun Anggaran 1996/1997. Jakarta.

Arsyad, L. 1997. Ekonomi Pembangunan. Gramedia. Jakarta.

Azis, I. 2004. Ilmu Ekonomi Regional dan Beberapa Aplikasi di Indonesia. Fakultas Ekonomi Universitas Indonesia. Jakarta.

Badan Kependudukan dan Keluarga Berencana Nasional. 2015. Pengertian Keluarga Sejahtera menurut BKKBN Banjarmasin. BKKBN Pusat Provinsi Kalimantan Selatan.

Badan Pusat Statistik. 2017. Berita Resmi Statistik. BPS Provinsi Sulawesi Utara, No. 80/09/71/Th. XI, Tanggal 4 September 2017.

Dumairy. 1997. Perekonomian Indonesia. Erlangga. Jakarta.

Guhardja. 1993. Pembangunan Sumberdaya Keluarga. Gunung Mulia. Jakarta.

Herawati, A. R. dan D. Junanto. 2003. Pemberdayaan Masyarakat Daerah (Kasus Pembangunan Masyarakat Pertanian di Beberapa Negara). STIALAN. Jakarta.

Jhingan, M. L. 2005. Ekonomi Pembangunan dan Perencanaan. PT. Raja Grafindo Persada. Jakarta. 
Kurniawati, T. 2015. Tingkat Kesejahteraan Pengrajin Bambu di Desa Sendari Kecamatan Mlati Kabupaten Sleman Daerah Istimewa Yogyakarta. Skripsi. Fakultas Ekonomi Universitas Negeri Yogyakarta.

Manning, Ch. 1986. The Green Revolution, Labour Displasement, Incomes and Wealth in Rural Java: a reassessment of trend during the Soeharto era. Flinders University. Adelaide.

Purwana, A. E. 2014. Kesejahteraan dalam Perspektif Ekonomi Islam. Ponorogo: STAIN.(Online),(http://stainponorogo.a c.id/index.php/justicia/article/download/ 91/,diakses 18 Juli 2017).

Salim, E. 1984. Perencanaan Pembangunan dan Pemerataan Pendapatan. Yayasan Idayu. Jakarta.

Sawidak, M. 1985. Analisis Tingkat Kesejahteraan Ekonomi Petani Transmigrasi di Delta Upang Sumatera Selatan. Tesis. Bogor: Fakultas Pasca Sarjana, Institut Pertanian Bogor.

Sawit, M. H. 1979. Peluang Kerja dan Berusaha di Pedesaan. Fakultas Ekonomi, Universitas Indonesia Press. Jakarta.

Sigit, H. 1980. Masalah Perhitungan Distribusi Pendapatan di Indonesia. LP3ES. Jakarta.
Soembodo, B. 2006. Pandangan Masyarakat Miskin Perkotaan Mengenai Kesejahteraan Sosial. Surabaya: Fakultas Ilmu Sosial dan Ilmu Politik Universitas Airlangga. (Online), (http:// journal.unair.ac.id/Downoad Full Paper sutama \%2520(1) \%2520 Benny\% 2520 (Miskin), diakses pada 18 Juli 2017).

Suandi. 2007. Modal Sosial dan Kesejahteraan Ekonomi Keluarga di Daerah Perdesaan Provinsi Jambi. [Disertasi]. Program Pasca Sarjana Institut Pertanian Bogor.

Sudibyo, B. 2005. Substansi Kemiskinan dan Kesenjangan. Dalam A. S. Dewanta, dkk. Kemiskinan dan Kesenjangan di Indonesia. Aditya Media. Yogyakarta.

Suharto, Edi. 2005. Membangun Masyarakat Memberdayakan Rakyat. Bandung: PT. Refika Pratama.

Sukirno, S. 1985. Ekonomi Pembangunan. Fakultas Ekonomi. Universitas Indonesia. Jakarta.

Suparlan, P. 1984. Kemiskinan di Perkotaan. Gramedia. Jakarta.

Thee Kian Wie. 1983. Pembangunan Ekonomi dan Pemerataan. LP3ES. Jakarta.

Todaro, M. P. 1987. Pembangunan Ekonomi di Dunia Ketiga. Erlangga. Jakarta. 